\title{
REENGINEERING WEBSITE UNIVERSITAS MA CHUNG MENGGUNAKAN FRAMEWORK "THE PERIODIC TABLE OF SEO SUCCESS FACTORS"
}

\author{
Arif M. Alhana Anul Habib. ${ }^{1)}$, Yudhi Kurniawan, S.Kom., M.MT. ${ }^{2}$ \\ 1) Sistem Informasi Universitas Machung \\ 2) Sistem Informasi Universitas Machung \\ E-mail : yudhi.kurniawan@machung.ac.id ${ }^{1)}, \underline{321310007 @ s t u d e n t . m a c h u n g . a c . i d}{ }^{2}$
}

\begin{abstract}
Abstraksi
Dalam upaya memperluas koneksi dan kemitraan dengan berbagai instansi luar, pihak Universitas membangun sebuah website resmi yang digunakan sebagai media informasi internal kepada pihak eksternal. Namun dalam pembuatan sebuah website tidak hanya melihat dari segi tampilan dan informasinya saja namun keramahan dengan mesin pencari yang kini menjadi salah satu sumber kunjungan terbesar perlu diperhatikan. Search Engine Optimization (SEO) adalah usaha-usaha dalam mengoptimasi website terhadap mesin pencari agar mendapatkan peringkat yang lebih baik SERP. Mesin pencari menggunakan algoritma tertentu dalam mengurutkan hasil pencarian yang relevan dengan kata kunci. Dengan mempraktekkan SEO itu berarti menyesuaikan website supaya bersahabat dengan algoritma tersebut sekaligus memudahkan mesin pencari dalam merayapi, mengindeks, dan memahami konten website. Oleh karena itu, perancangan kembali official website Ma Chung dengan menerapkan faktor-faktor penentu keberhasilan di hasil pencarian dibutuhkan sebagai upaya mengoptimalkan kinerja website terhadap mesin pencari. Reengineering official website Ma Chung ini menggunakan framework "The Periodic Table of SEO Success Factors".
\end{abstract}

\section{Kata Kunci :}

Perancangan Ulang, Situs, Mesin Pencari, Optimasi Mesin Pencari (SEO), SERP, SEO Internal, SEO Eksternal

\begin{abstract}
The important role of website to Ma Chung University is building profiles in order to make the outside community more familiar with the University. However, there are not only terms of appearance and information in the making of a website which being consideration, but the search engine friendliness too which nowadays becomes the largest source of visits. Optimizing website to search engine in order to get better rank in SERP is using Search Engine Optimization (SEO). Search engines use particular algorithms to sort the search results which is relevant to the keywords. In practicing SEO, it means customizing the website to be friendly with the algorithm as well as facilitate search engines in crawling, indexing, and understanding the website content. Applying the determinants of success in search results is needed as an effort to optimize website performance against search engines needs to apply. This reengineering using "The Periodic Table of SEO Success Factors".
\end{abstract}

\section{Keywords :}

Reengineering, Website, Search Engine, Search Engine Optimization (SEO), SERP, On-Page SEO, OffPage SEO 


\section{Pendahuluan}

Website memiliki peranan penting terhadap pihak Universitas dalam membangun profil agar lebih dikenal di masyarakat luar. Itu mengapa mengoptimalkan kinerja website terhadap mesin pencari terutama Google dan Bing adalah sebuah keharusan. Hasil pencarian pada search engine atau yang disebut Search Engine Result Page (SERP) merupakan hal penting yang perlu teknik penanganan khusus untuk menjadikan website tampil pada urutan pertama di mesin telusur. Dan teknik ini dinamakan SEO (Search Engine Optimization). Dengan menerapkan SEO berarti telah memudahkan mesin telusur dalam merayapi, mengindeks, dan memahami konten website.

Sebuah Search Engine mempunyai algoritma penentuan yang dapat meng-crawl isi website secara menyeluruh sebagai pertimbangan untuk mendapatkan peringkat teratas.

Dalam penelitian ini, peneliti menggunakan penerapan metode Search Engine Optimization (SEO) dengan framework "The Periodic Table of SEO Success Factors" dari Search Engine Land. Hasil analisa ini akan menghasilkan

sebuah laporan rekomendasi yang diperuntunkan kepada pihak Universitas Ma Chung maupun Universitas dan instansi lain sebagai bahan pertimbangan yang efektif dalam meningkatkan jumlah pengunjung dari mesin pencari dan mendapatkan posisi teratas pada hasil pencarian (SERP).

\section{Tinjauan Pustaka}

Hasil penelitian dari peneliti sebelumnya:

Penerapan Teknik SEO (Search Engine

Optimization SEO) pada Website Dalam Strategi

Pemasaran Melalui Internet (2014). Penelitian yang dilakukan oleh Rony Baskoro Lukito; Cahya Lukito; Deddy Arifin dari Program Studi Ilmu Komputer, Universitas Binus ini membahas mengenai seberapa penting SEO dalam internet marketing. Pembahasan pada jurnal tersebut mengarah pada optimasi di bagian On-Page termasuk juga pembahasan mengenai teknik dalam pemilihan domain yang tepat terhadap barang dan jasa yang akan dipasarkan. Pembahasan keyword juga dibahas secara detail pada penelitian terdahulu ini. Penelitian ini membahas tentang penerapan Search Engine Optimization pada bagian On-Page, namun juga membahas pada bagian Off-Page SEO. [1]

2.1 Search Engine (Mesin Pencari)

Program yang digunakan untuk menampilkan permintaan tipikal seseorang dalam mencari hal yang dinginkan melalui internet. Ada ribuan, bahkan jutaan halaman web yang memiliki informasi yang relevan dengan kata kunci pencarian. [3]

\subsection{Search Engine Optimization (SEO)}

Search Engine Optimization adalah proses mendapatkan lalu lintas dari hasil pencarian "bebas","organik", "editorial" atau "alami" di mesin pencari. Semua mesin pencari terutama Google, Bing dan Yahoo memiliki hasil pencarian di mana halaman web dan konten lainnya seperti gambar, video atau konten lokal ditampilkan dan diurutkan berdasarkan perkiraan mesin pencari yang paling relevan bagi pengguna. [2]

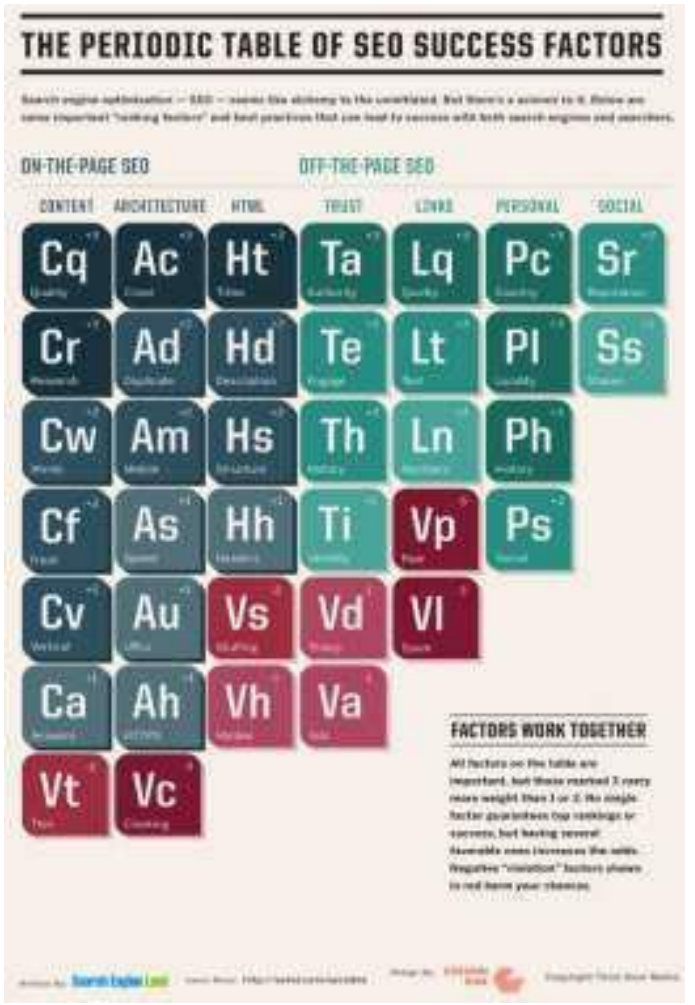

Gambar 2.1 The Periodic Table of SEO Success Factors

2.3 The Periodic Table of SEO Success Factors Merupakan framework yang dirancang oleh Search Engine Land dan di desain oleh Column Five Media. Framework ini menggambarkan faktor-faktor yang akan membantu website berhasil mendapatkan lebih banyak pengunjung dari mesin pencari secara organik. Terbagi menjadi tiga bagian pembahasan yakni On-Page SEO, Off-Page SEO dan Violations secara lebih mendalam dan memberikan tutorial optimasi mesin pencari. Mungkin tampak seperti alkimia untuk yang belum tahu. Tapi ada ilmu untuk itu. 
Mesin telusur memberikan penghargaan atau imbalan kepada setiap website pada direktori mereka yang merancang secara tepat faktorfaktor penting atau sinyal peringkat. Untuk informasi selengkapnya mengenai model framework dapat dilihat pada gambar 2.1 [2]

\section{Metode Penelitian}

Adapun urutan metode penelitian, diantaranya:

1. Pengumpulan Data

Membaca dan mempelajari literatur-literatur serta melakukan pencarian referensi yang akan digunakan berkaitan dengan Search Engine Optimization (SEO), crawler, keyword, meta tag dari berbagai jurnal, paper, buku, situs dan referensi lainnya sehinga memperkuat dalam proses analisis pada objek nantinya.

2. Analisis dan Rekomendasi

Dalam penelitian ini akan menggunakan Framework dari SearchEngineLand.com, "The Periodic Table of SEO Success Factors" yang membahas 3 bagian yakni On-Page SEO (terdiri dari 16 elemen), Off-Page SEO (terdiri dari 13 elemen) dan Violations (terdiri dari 8 elemen). Analisa akan dilakukan pada url website machung.ac.id dengan penilaian apakah objek penelitian telah memenuhi faktor penting yang mempengaruhi posisi pada Search Engine Result Page (SERP).

\section{Kesimpulan dan Saran}

Mendokumentasikan hasil dari analisis website dari mulai tahap studi literatur hingga tahap pengambilan keputusan kedalam suatu bentuk laporan yang berisi dokumentasi, kesimpulan, dan rekomendasi terhadap penelitian ini.

\section{Hasil dan Pembahasan}

Dari metode penelitian diatas, didapatkan hasil:

\subsection{Pengumpulan Data}

Tahap pengumpulan data yang peneliti terbagi mejadi 2, diantaranya:

\subsubsection{Observasi Objek}

Peneliti melakukan pengumpulan data dengan cara pemeriksaan dari segala sisi dari official website Universitas Ma Chung dan memecahnya menjadi beberapa bagian, diantaranya:

- $\quad$ Pengaturan Server dan Code

Peninjauan dalam pengaturan server dan

code dilakukan dengan cara memonitornya menggunakan bantuan aplikasi atau juga dapat memeriksanya lansung baik dari server dan embed website.

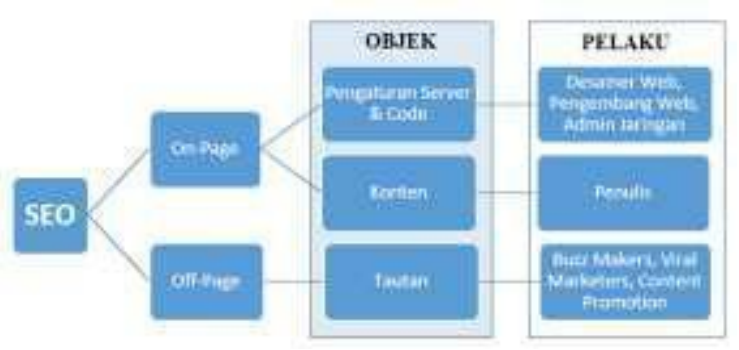

Gambar 4.1 Ruang Lingkup Observasi Objek Penelitian

Pemeriksaan pada bagian ini akan membahas diantaranya:

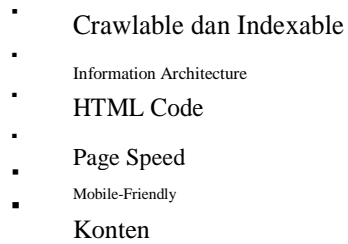

Peninjauan pada bagian konten termasuk di dalam penanganan bagian internal atau seorang penerbit, adapun titik-titik yang akan dianalisa nantinya diantaranya:

$$
\text { Readibility }
$$

- Duplicate Konten (Internal \& Eksternal)

$$
\begin{array}{ll}
\text { - } & \text { Thin Content } \\
\text { - } & \text { Comptetitor Content } \\
& \text { Keyword }
\end{array}
$$

Seberapa relevan keyword dengan isi konten yang ada menjadi titik utama dalam pembahasan disini. Selain itu juga ada kriteriakriteria yang menjadi acuan mesin telusur sehingga suatu laman mendapatkan posisi terbaik di Search Engine Result Page (SERP).

$$
\text { - Tautan }
$$

Tautan atau link menjadi hal penting dalam objek penelitian ini, apakah seluruh url yang ada pada website telah teroptimasi secara optimal dan berkualitas. Berikut ini beberapa bagian yang akan dibahas lebih lanjut:

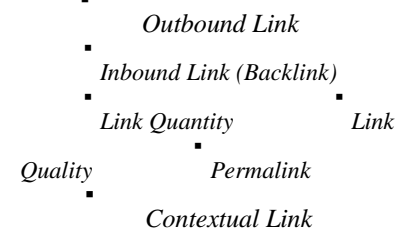

Ketiga objek penelitian diatas akan disesuaikan dan dikondisikan dengan menggunakan framework "The Periodic Table of SEO Success Factors". Untuk selengkapnya dapat dilihat pada gambar 4.1.

\subsubsection{Studi Literatur}


Studi Literatur adalah pengumpulan data dengan cara mengumpulkan literatur seperti jurnal, paper dan referensi bacaan-bacaan yang di internet termasuk buku dan media online seperti website dan jurnal online yang ada kaitannya dengan judul penelitian, sehingga memperkuat dalam proses analisis. Metode ini digunakan untuk mengetahui landasan teori, langkah analisis dan data yang akan dianalisis.

Dalam upaya memperkaya data awal sebelum nantinya akan dibahas, peneliti menggunakan bantuan dari beberapa web-tools untuk membantu melihat status terkini dari objek penilitian, diantaranya:

- Google Search Console

- Bing Webmaster

- SEO Quake

- $\mathrm{MOZ}$

- W3C Markup Validation

- GTMetrix

\subsection{Analisis dan Penjabaran Framework}

Pembahasan terbagi menjadi 3 bagian yakni penjabaran pada bagian On-Page SEO, Off-Page $S E O$ dan pelanggaran (violations). Perlu diingat bahwa setiap faktor SEO bekerja secara kombinasi. Tidak ada faktor $S E O$ tunggal yang akan menjamin peringkat pada hasil pencarian di mesin telusur.

Berikut beberapa hal penting sebagai faktor keberhasilan dan best practice untuk mengarahkan website diposisi terbaik pada hasil penelusuran di search engine.

\subsubsection{Faktor-Faktor On-Page SEO Bagian}

optimasi mesin pencari yang hampir seluruhnya dalam kendali pihak internal yang mengelolah website. Apa jenis konten yang dipublikasikan? Apakah website memberikan petunjuk HTML penting yang membantu mesin pencari dan pengguna menentukan relevansi? Apakah arsitektur website telah membantu atau menghambat mesin pencari dalam merayapi website? Hal-hal seperti itu yang akan dibahas pada On-The-Page SEO.

\section{- Content}

Memiliki konten yang berkualitas sudah pasti menciptakan dasar yang kuat untuk mendukung semua upaya faktor $S E O$ lainnya.

Tabel 4.1 Content Factor

\begin{tabular}{|c|c|c|}
\hline $\begin{array}{c}\text { Factor } \\
\text { Code }\end{array}$ & Segment & \multicolumn{1}{c|}{ Indicators } \\
\hline $\mathbf{C q}$ & Quality & $\begin{array}{l}\text { Apakah halaman ditulis } \\
\text { dengan baik \& memiliki }\end{array}$ \\
\hline
\end{tabular}

\begin{tabular}{|l|l|l|}
\hline & & $\begin{array}{l}\text { kualitas konten yang cukup } \\
\text { besar? }\end{array}$ \\
\hline $\mathbf{C r}$ & Research & $\begin{array}{l}\text { Apakah pihak Universitas } \\
\text { telah meneliti kata kunci } \\
\text { yang orang mungkin } \\
\text { gunakan untuk } \\
\text { menemukan konten } \\
\text { website? }\end{array}$ \\
\hline Cw & Words & $\begin{array}{l}\text { Apakah halaman telah } \\
\text { menggunakan kata \& frasa } \\
\text { yang diberharap mereka } \\
\text { akan ditemukan? }\end{array}$ \\
\hline $\mathbf{C f}$ & Fresh & $\begin{array}{l}\text { Apakah konten baru dan } \\
\text { juga membahas mengenai } \\
\text { sesuatu terkini? }\end{array}$ \\
\hline $\mathbf{C v}$ & Vertical & $\begin{array}{l}\text { Apakah website memiliki } \\
\text { gambar, konten lokal, } \\
\text { berita, video atau konten } \\
\text { vertikal lainnya? }\end{array}$ \\
\hline Ca & Answers & $\begin{array}{l}\text { Apakah konten berubah } \\
\text { menjadi jawaban langsung } \\
\text { dalam hasil pencarian? }\end{array}$ \\
\hline
\end{tabular}

\section{Content Quality (Cq)}

Kondisi sekarang:

- Banyak halaman kosong / kurang lengkap

- Anchor link tidak memiliki tujuan

- Laman tidak memiliki gambar utama

- Kekurangan konten / terlalu pendek

- Fitur share tidak berfungsi

- Konten tidak up to date

Konten kurus

Rekomendasi:

-

Penyajian konten menarik (kolaborasi

. teks, gambar/media lainnya)

Konten berbobot (> 500 kata)

Konten diperbarui setiap hari dengan berbagai tema

baik tentang event Ma Chung,

berita maupun kegiatan internal lainnya

- Usung konten yang viral namun layak diberitakan dan relevan dengan kata kunci.

\section{Content / Keyword Research (Cr)}

Kondisi sekarang:

- Konten seadanya

- Kata kunci yang kurang bervariasi

- Pembahasan kurang luas

- Merumuskan kata kunci turunan dari setiap kategori pembahasan

Rekomendasi:

- Menggunakan tools bantuan dalam meneliti keyword yang banyak dicari terkait Universitas seperti:

- Ubersuggest.io

- Keywordtool.io

- SEMrush

- Google Analytics 
- Terjun di forum, jejaring sosial dan lainnya untuk menemukan kata kunci berpeluang besar yang dapat diusung.

\section{Content Words / Use of Keywords (Cw)}

Kondisi sekarang sudah untuk keyword utama

"Ma Chung", Namun penggunaan keyword masih belum optimal di setiap halamannya (Latent Semantic Indexing / LSI Keyword dan

Long Tail Keyword kurang divariasi).

Rekomendasi

- Memastikan konten dan keyword yang diincar relevan

- Setiap halaman paling tidak dioptimasi untuk 1 keyword

- Menyertakan keyword di judul, konten dan URL

- Variasikan niche keyword kedalam LSI Keyword dan Long Tail Keyword.

\section{Content Freshness (Cf)}

Kondisi sekarang konten jarang diperbarui.

Rekomendasi:

- Konten diperbarui setiap hari

- Tema konten pembahasan beragam

- Kejadian terkini: Publikasi konten yang membahas mengenai momen penting yang dirasa perlu dipublikasi ke masyarakat luar.

- Acara terbaru / event: Publikasi acara dan kegiatan mahasiswa.

- Acara rutin berulang: Publikasi berita acara tahunan yang digelar dan mendapatkan respon dari berbagai kalangan media seperti Ma Chung Festival (MCF).

- Memanfaatkan peluang Query Deserved Freshness (QDF) / Trending topic di masyarakat umum baik pengetahuan, event atau penelitian (bukan gosip atau berita sepak bola dll).

\section{Content Vertical (Cv)}

Kondisi sekarang: Konten vertical lainnya sudah ada termasuk gambar, video dll. Namun sebagian halaman tidak muncul gambar, penggunaan media kurang (maps, video dll) dan sedikitnya berita local.

- Menggunakan gambar yang berhubungan dan menjelaskan konten

- Memastikan resolusi gambar dan mengompresnya agar optimal Tools: jpegmini.com/main/shrink_photo

- Menambahkan atribut alt pada gambar sesuai keyword. Penerapan: <img $\mathrm{src}=$ "images.jpg" alt="keyword">

- Mengusung berita lokal baik internal maupun eksternal namun masih dalam tema yang selaras dengan program studi maupun pengetahuan. penelitian (bukan gosip atau lainnya yang tidak sejenis).

\section{Content Answer / Direct Answer (Ca)}

Kondisi sekarang halaman FAQ kosong \& konten website tidak mengusung tema tanyajawab

Rekomendasi:

- Memperbaiki dan melengkapi secara detail halaman FAQ (Frequently Asked Questions)

- Buat konten dengan tema yang menarik dan didalamnya terdapat konten tanya jawab yang terkait dengan pembahasan konten tersebut. Selipkan keyword pada kalimat pertanyaan dan jawaban.

- Architecture

Struktur situs yang tepat dapat membantu memudahkan perayapan mesin pencari.

Tabel 4.2 Architecture Factor

\begin{tabular}{|c|c|l|}
\hline $\begin{array}{c}\text { Factor } \\
\text { Code }\end{array}$ & Segment & \multicolumn{1}{|c|}{ Indicators } \\
\hline Ac & Crawl & $\begin{array}{l}\text { Apakah mesin telusur } \\
\text { dapat dengan mudah } \\
\text { merayapi halaman pada } \\
\text { website? }\end{array}$ \\
\hline Ad & Duplicate & $\begin{array}{l}\text { Apakah website dapat } \\
\text { menanggani duplikasi } \\
\text { konten dengan baik? }\end{array}$ \\
\hline Am & Mobile & $\begin{array}{l}\text { Apakah website telah } \\
\text { berjalan dengan } \\
\text { sempurna pada perangkat } \\
\text { mobile ataupun } \\
\text { sejenisnya? }\end{array}$ \\
\hline As & Speed & $\begin{array}{l}\text { Apakah website dimuat } \\
\text { dengan cepat dan lancar? }\end{array}$ \\
\hline$A$ A & URLs & $\begin{array}{l}\text { Apakah URL } \\
\text { mengandung kata kunci } \\
\text { yang berkaitan dengan } \\
\text { topik halaman? }\end{array}$ \\
\hline
\end{tabular}

Site Crawlability (Ac)

Kondisi sekarang:

\footnotetext{
Sudah menggunakan Google Webmaster, belum untuk Bing dan Yandex Webmaster.

Belum men -submit sitemap.xml pada search console.
}

Rekomendasi:

Submit website ke tools official mesin pencari untuk memudahkan bot search 
engine melakukan crawl untuk di indeks. (Daftarkan ke Google Search Console, Bing Webmaster, Yandex Webmaster dll.) Implementasikan structured data untuk mempermudah mesin pencari dalam mengindeks, untuk mempelajarinya bisa mengunjungi;

http://schema.org/docs/schemas.html

Selain dalam bentuk html, memanfaatkan sitemap.xml memberi tahu mesin pencari

tentangdirayapi. halaman yang tersedia untuk Duplication / Canonicalization (Ad)

Kondisi sekarang:

- Halaman website tidak menggunakan cononical URLs (rel="canonical")

- Halaman yang sama / kosong tidak di redirect.

Rekomendasi:

- Menggunakan canonical di setiap halaman, $<$ link rel="canonical" href="\#"/>; \#= url tiap halaman. Letakkan di dalam tag <head>

- Manfaatkan redirect untuk menangani halaman 404 maupun link yang berbeda dengan konten yang sama.

\section{Mobile Friendly (Am)}

Kondisi sekarang website tidak mobile-friendly atau responsive.

- Memperbaiki struktur template supaya ramah di perangkat mobile, cek melalui tools:

- Google Mobile-Friendly Test

- Bing Mobile Friendliness Test

- Memperhatikan penanganan khusus pada bagian

- Konfigurasi viewport

(Viewport config.)

- Konfigurasi zoom

(Zoom configuration)

- Lebar konten (Content width)

- Pembacaan teks (Readability of text)

- Jarak link dan konten lainnya

\section{Site Speed (As)}

Kondisi sekarang:

- Ukuran file gambar yang masih besar

- Minify JavaScript belum

optimal Rekomendasi:

- Penggunaan media gambar sebaiknya di compress terlebih dahulu sebelum diupload. Gunakan: jpegmini.com

- $\quad$ Jumlah file .js dan .css di <head> perlu diperhatikan

- Gunakan tools bantuan analisa seperti Gtmetrix dan Google PageSpeed Insight dalam memperbaiki bagian script-nya
URLs (Au)

Hal yang perlu diperhatikan:

- Keyword pada URL tidak sesuai dengan versi bahasa

- Susunan permalink kurang dioptimalkan

- Banyak url bisa diakses tapi

kosong Rekomendasi:

- Sesuaikan nama url dengan judul dan bahasa yang digunakan (jika versi indonesia maka keyword pada url juga bahasa Indonesia)

- Menggunakan permalink/url yang ringkas dan mengandung keyword utama

- Memastikan seluruh URL yang aktif terdapat konten dan bukan halaman kosong.

HTTPS / Secure Site (Ah)

Kondisi sekarang:

- Belum memiliki Secure Socket Layers (SSL) Certificate / masih menggunakan HTTP.

Rekomendasi:

- Menggunakan SSL/HTTPS, selain untuk meningkatkan authority, keamanan data juga pasti terjaga.

- Sertifikat SSL bisa dibeli di registrar domain itu sendiri atau tempat lain seperti namecheap.com, godaddy.com dan beberapa tempat lainnya yang terpercaya.

- HTML

HTML adalah kode dasar yang digunakan untuk membuat halaman website. Mesin telusur dapat mengambil informasi penting dari elemen HTML tertentu.

\section{HTML Title Tag (Ht)}

Kondisi sekarang:

- Title tag yang sama di banyak halaman

- Keyword pada title tag tidak

relevan Rekomendasi:

- Variasikan penggunaan HTML Title tag pada setiap halaman sesuai judul yang diusung (Relevankan title tag dengan tag $<\mathrm{H} 1>)$

- Hindari penggunaan title tag yang sama disetiap halaman

Tabel 4.3. HTML Factor

\begin{tabular}{|c|c|l|}
\hline $\begin{array}{c}\text { Factor } \\
\text { Code }\end{array}$ & Segment & \multicolumn{1}{c|}{ Indicators } \\
\hline $\mathrm{Ht}$ & Titles & $\begin{array}{l}\text { Apakah tag judul } \\
\text { HTML berisi kata } \\
\text { kunci yang relevan } \\
\text { dengan topik halaman? }\end{array}$ \\
\hline $\mathrm{Hd}$ & Description & $\begin{array}{l}\text { Apakah meta tag } \\
\text { deskripsi } \\
\text { menggambarkan } \\
\text { ringkasan mengenai } \\
\text { suatu laman website? }\end{array}$ \\
\hline
\end{tabular}




\begin{tabular}{|l|l|l|}
\hline $\mathrm{HS}^{\mathrm{t}}$ & Structure & $\begin{array}{l}\text { Apakah halaman } \\
\text { menggunakan data } \\
\text { terstruktur untuk } \\
\text { meningkatkan konten } \\
\text { di dalamnya? }\end{array}$ \\
\hline $\mathrm{Hh}^{\mathrm{t}}$ & Headers & $\begin{array}{l}\text { Apakah headline \& } \\
\text { subheads menggunakan } \\
\text { tag header dengan kata } \\
\text { kunci yang relevan? }\end{array}$ \\
\hline
\end{tabular}

\section{Meta Description Tag (Hd)}

Kondisi sekarang seluruh halaman tidak memiliki meta description tag.

\section{Rekomendasi:}

- Gunakan meta description tag di tag $<$ head $>$ pada setiap halaman

Penerapan:

$<$ head $>$

$<$ title $>$ HTML Title</title>

$<$ meta name="description" content="deskripsi singkat halaman" $>$

$</$ head $>$

- Attribute content maksimum 150-160 huruf

- Relevan dengan isi halaman (terdapat 1 keyword)

- Buat semenarik mungkin untuk diklik

Structured Data (Hs)

Kondisi sekarang belum memanfaatkan structured data markup schema.org atau microformats

Rekomendasi:

- Memanfaatkan Structured data markup untuk memperkaya tampilan pada hasil pencarian,kunjungiSchema:

http://schema.org Microformats:

http://microformats.org/

- Gunakan tools Google's Structured Data Markup Helper untuk pembuatan file structured data secara praktis.

Kunjungi google.com/webmasters/markuphelper/

\section{Header Tags (Hh)}

Kondisi sekarang tidak menggunakan Header tags

\section{Rekomendasi:}

- Manfaatkan header tag sebagai judul / headline halaman $\langle\mathrm{H} 1\rangle$ untuk judul utama, $<\mathrm{H} 2>$ sub-judul, $\langle\mathrm{H} 3>$ sub dari sub-judul dan seterusnya hingga $\langle\mathrm{H} 6>$

- Gunakan <H1> hanya 1x di 1 halaman untuk mengoptimalkannya secara maksimal dan harus menyertakan kata kunci terbaik.

\subsubsection{Faktor-Faktor Off-Page SEO}

Bagian optimasi mesin pencari dimana penerbit tidak memiliki kontrol langsung. Pengaruh SERP ditentukan oleh interaksi media sosial, kawasan pencarian dan riwayat website.

- Trust

Mesin pencari dapat memutuskan untuk mempercayai link atau akun sosial, dan akan kah hal tersebut juga membuat mereka belajar untuk mempercayai website? Ya, banyak pakar yang percaya bahwa kepercayaan situs memainkan peran besar dalam sebuah keberhasilan atau kegagalan dari perspektif pencarian.

\section{Authority (Ta)}

\section{Rekomendasi:}

- Memastikan tidak adanya review negatif dari pembaca di berbagai media online termasuk google review dan sosial media.

- Perbaiki elemen-elemen One-Page SEO, konten diperbarui setiap hari, berkualitas \& jauhi duplikasi konten, sediakan fitur share artikel.

Tabel 4.4. Trust Factor

\begin{tabular}{|c|l|l|}
\hline $\begin{array}{c}\text { Factor } \\
\text { Code }\end{array}$ & Segment & \multicolumn{1}{c|}{ Indicators } \\
\hline Ta $^{-3}$ & Authority & $\begin{array}{l}\text { Apakah link, share dan } \\
\text { faktor lain membuat } \\
\text { website mempunyai } \\
\text { otoritas yang terpercaya? }\end{array}$ \\
\hline Te $^{-2}$ & Engage & $\begin{array}{l}\text { Apakah pengunjung } \\
\text { menghabiskan waktu } \\
\text { membaca atau sekedar } \\
\text { datang dan pergi dengan } \\
\text { cepat? }\end{array}$ \\
\hline Th $^{2}$ & History & $\begin{array}{l}\text { Apakah situs ataupun } \\
\text { domain telah ada sejak } \\
\text { lama dan beroperasi } \\
\text { dengan cara yang sama? }\end{array}$ \\
\hline$T^{2}$ & Identity & $\begin{array}{l}\text { Apakah situs } \\
\text { memverifikasi } \\
\text { identitasnya dan } \\
\text { mengekspos penulis? }\end{array}$ \\
\hline
\end{tabular}

\section{Engagement (Te)}

\section{Rekomendasi:}

- Minimalkan rate dari pogosticking dan bounce sekecil mungkin dengan menyediakan konten yang berbobot.

- Lihat konten berpeluang di Google Analytics dan memperbaikinya dengan kriteria filter: Page View (Tinggi), Avg. Time on Page (Rendah), Bounce Rate (Tinggi), \% Exit (Tinggi).

- Perbaikan berhasil jika Avg. Time on Page meningkat sedangkan Bounce Rate dan \% Exit menurun dari waktu ke waktu.

History (Th) 
Rekomendasi:

- Memastikan selalu notifikasi yang ada pada Google Webmaster (Search Console) maupun di tools lainnya sperti Bing dan Yandex Webmaster.

\section{Identity (Ti)}

- Memanfaatkan sinyal identitas menggunakan Bing Webmaster Tools, Google Search Console, Yandex Webmaster dan lainnya.

- Menautkan link situs di seluruh akun official sosial media maupun forum luar (halaman profile / about)

- Memanfaatkan layanan local directory dan mensubmit identitas Universitas Ma Chung ke dalamnya (Google My Business)

- Cantumkan link official sosial media pada halaman about atau sejenis di website.

- Cantumkan nama penulis beserta info lain tanggal publish di setiap halaman (terutama halaman berita, ulasan dan artikel)

- $\quad$ Links

Mesin pencari sangat bergantung pada analisa link sebagai cara untuk meningkatkan relevansi pencarian para penguna. Tidak semua link sama nilainya, ada yang berbobot dan ada yang tidak.

Tabel 4.5. Links Factor

\begin{tabular}{|c|c|l|}
\hline $\begin{array}{c}\text { Factor } \\
\text { Code }\end{array}$ & Segment & \multicolumn{1}{|c|}{ Indicators } \\
\hline Lq & Quality & $\begin{array}{l}\text { Apakah link berasal dari } \\
\text { website terpercaya, } \\
\text { berkualitas dan } \\
\text { merupakan website yang } \\
\text { dihormati? }\end{array}$ \\
\hline Lt & Text & $\begin{array}{l}\text { Apakah link mengarah } \\
\text { ke halaman } \\
\text { menggunakan kata-kata } \\
\text { yang relevan dengan } \\
\text { keyword } \text { halaman } \\
\text { tersebut? }\end{array}$ \\
\hline Ln & Numbers & $\begin{array}{l}\text { Apakah link luar } \\
\text { (backlink) banyak yang } \\
\text { mengarah ke halaman } \\
\text { website Ma Chung? }\end{array}$ \\
\hline Lq & Quality & $\begin{array}{l}\text { Apakah link berasal dari } \\
\text { website terpercaya, } \\
\text { berkualitas dan } \\
\text { merupakan website yang } \\
\text { dihormati? }\end{array}$ \\
\hline
\end{tabular}

\section{Link Quality (Lq)}

Rekomendasi:

- Pertahankan dan perbanyak backlink dari website besar yang memiliki relevansi dengan topik website Ma Chung
- Jalin kerjasama dengan media-media besar sehingga berpeluang untuk mendapatkan ulasan (backlink) di konten mereka.

- Terus menyajikan konten bernilai dan tingkat validitas informasinya dapat dipertanggung jawabkan.

\section{Link Text / Anchor Text (Lt)}

Rekomendasi:

- Meningkatkan kualitas website dan kepercayaan di mata publik sebagai website official.

- Branding nama "Ma Chung", "Universitas Ma Chung" atau lainnya yang terkait agar lebih dikenal di masyarakat luar sehingga mendorong situs lain memberikan link lewat anchor text "Ma Chung".

\section{Number of Links (Ln)}

- Mendapatkan link dari website yang dihormati jauh lebih penting.

- Buat konten berkualitas dan menarik perhatian sehingga banyak yang share secara natural.

- Utamakan perolehan link secara contextual link (link dalam teks) di konten

- Jauhi penggunaan perangkat lunak otomatis seperti auto-commend bot, web directory submitter dan lainnya.

- Melakukan forum marketing dan analisa backlink berkualitas milik kompetitor.

- Beberapa tools pendukung bisa dimanfaatkan diantaranya: SEMrush, MOZ OpenSite Explorer, Ahrefs, Majestic SEO, Open Link Profiler, SEO Spy Glass.

\section{- Personal}

Dengan perkembangan era saat ini pada mesin telusur, tidak ada peroranghan yang melihat persis hasil pencarian yang sama. Semua orang mendapat mendapatkan pengalaman penjelajahan yang disesuaikan sampai tingkat tertentu menurut kawasan, waktu hingga bahasa.

Tabel 4.6. Personal Factor

\begin{tabular}{|l|l|l|}
\hline $\begin{array}{c}\text { Factor } \\
\text { Code }\end{array}$ & Segment & \multicolumn{1}{c|}{ Indicators } \\
\hline $\mathbf{P C}$ & Country & $\begin{array}{l}\text { Apakah website relevan } \\
\text { dengan target penonton } \\
\text { mereka di suatu Negara? }\end{array}$ \\
\hline $\mathbf{P |}$ & Locality & $\begin{array}{l}\text { Apakah website relevan } \\
\text { dengan kota atau daerah } \\
\text { yang ditargetkan? }\end{array}$ \\
\hline $\mathbf{P h}$ & History & $\begin{array}{l}\text { Apakah seseorang secara } \\
\text { teratur mengunjungi situs } \\
\text { atau bahkan } \\
\text { difavoritkan? }\end{array}$ \\
\hline
\end{tabular}




\begin{tabular}{|l|l|l|}
\hline$P_{5}$ & Social & $\begin{array}{l}\text { Apakah seseorang } \\
\text { maupun banyak orang } \\
\text { secara sosial } \\
\text { memfavoritkan website? }\end{array}$ \\
\hline
\end{tabular}

Country (Pc)

Rekomendasi:

- Memperbaiki setiap versi bahasa di website termasuk keselarasan seluruh konten, url, navigasi, sidebar dan footer. Disesuaikan seluruhnya dengan tiap versi bahasa.

- Ada baiknya membagi direktori website menjadi setiap versi Bahasa.

- Hosting website Ma Chung di IP Indonesia (Pertahankan), dan memastikan respon server cepat dan stabil.

Locality (Pi)

Rekomendasi:

On-Page-SEO telah dioptimalkan dengan

baik

Klaim dan pastikan daftar Google My Business (GMB) telah terisi penuh serta

mendapatkan cukup review positif.

Usahakan profil tampil di Google Search, Google

Maps dan Google+.

Manfaatkan Organic Local SEO,

contoh mengoptimalkan "kata kunci +

kota”

- Menghubungkan ke konten lokal dan

membangun link dari website lokal.

Personal History (Ph)

Pastikan bahwa konten disajikan secara

menakjubkandan bernilai sehingga

- membuat pengunjung akan kembali lagi.

Konten selalu diperbarui dan menarik

perhatian untuk dibaca ataupun

membuatnya dilike, ditanggapi dan dishare

di berbagai sosial media.

User Experience ditingkatkan (Mobile-Friendly)

Social Connections (Ps)

Menghidupkan official akun sosial media Universitas Ma Chung untuk aktif

berkomunikasi dengan masyarakat luar.

Bangun reputasi baik dengan menjalin hubungan di media sosial seperti contohnya menanggapi respon, ikut berkomentar di

forum luar ataupun mengusung konten untuk suatu perorangan maupun organisasi

dipublikasi di sosial media dan website.

(Berinteraksi dengan follower dan influencer)

- Socials

Interaksi media sosial menjadi alternative faktor penilaian peringkat mesin pencari selain backlink.

\begin{tabular}{|c|c|l|}
\hline $\begin{array}{c}\text { Factor } \\
\text { Code }\end{array}$ & Segment & \multicolumn{1}{|c|}{ Indicators } \\
\hline Sr & Reputation & $\begin{array}{l}\text { Apakah perorangan atau } \\
\text { organisasi yang } \\
\text { dihormati menyukai, } \\
\text { merespon maupun } \\
\text { membagikan tautan } \\
\text { website di sosial media? }\end{array}$ \\
\hline 55 & Shares & $\begin{array}{l}\text { Apakah banyak konten } \\
\text { website yang telah } \\
\text { dibagikan di sosial } \\
\text { media? }\end{array}$ \\
\hline
\end{tabular}

Social Reputation (Sr)

Rekomendasi:

- Publikasi konten dilakukan serentak di seluruh media (website, sosial media /

. forum luar)

- Membuat konten bernilai dan shareable.

Mendengarkan dan merespon para follower yang ada di sosial media

Menjalin hubungan baik dengan follower dan influencer / buzzer (orang yang mampu mempengaruhi follower, contohnya tokoh publik, selebgram, artis dan orang terkenal lainnya)

Social Shares

(Ss) Rekomendasi:

-

Menyediakan fitur share di setiap halaman (diutamakan konten pembahasan berita, event atau info penting lainnya)

Konten butuh inovasi sehingga banyak di share di sosial media dan menarik untuk dibaca.

\subsubsection{Pelanggaran \& Penalti (Violations)}

Mesin pencari ingin para pengelola websiite melakukan $S E O$ karena dapat membantu meningkatkan hasil pencarian pada mesin pencari mereka. Beberapa akun official dari mesin telusur memberikan bantuan dalam bentuk pedoman, postingan blog bahkan video untuk memberikan pengetahuan dan mendorong teknik $S E O$ tertentu. Namun, ada beberapa teknik dimana mesin pencari menganggapnya sebagai suatu kecurangan, spam dan biasa disebut Black

Hat SEO. Hukuman yang diberikan mengakibatkan halaman website mengalami penurunan peringkat di hasil pencarian (SERP) atau yang lebih buruk lagi, website telah dihilangkan pada hasil pencarian. Teknik-teknik yang dilanggar kebanyakan dimaksudkan untuk menipu atau memanipulasi pemahaman mesin pencari dalam mempertimbangkan peringkat di hasil

Contoh

"Thin" or "Shallow" Content 
Hindari / Jangan dilakukan:

Konten tidak original atau Copy-paste konten secara langsung tanpa di ulas

(Duplicatekembali denganContent). tata bahasa sendiri AGC (Auto Generated Content).

Low quality content, biasanya halaman kurang dari 200 kata.

Cloaking (Vc)

Hindari / Jangan dilakukan:

- Mencurangi mesin pencari dan pembaca. Dimana menampilkan dua bagian terpisah dari konten halaman web tunggal. Teks pertama berfungsi untuk crawling, sedangkan yang kedua diperlihatkan kepada pembaca yang sebenarnya.

Keyword Stuffing (Vs)

Hindari / Jangan dilakukan:

Pengulangan kata kunci yang sering di konten

Hidden Text (Vh)

Hindari / Jangan dilakukan:

Menyembunyikan teks baik dalam bentuk style, font dan tampilan.

Piracy / DMCA Takedowns (Vd)

Hindari / Jangan dilakukan:

- Pembajakan konten

- Copy-paste konten dari website lain tanpa re-write / sumber link

Ads / Top Heavy Layout (Va)

Hindari / Jangan dilakukan:

- Menutupi konten dengan iklan

- Penempatan iklan dibawah judul

Paid Links (Vp)

Hindari / Jangan dilakukan:

- Membeli backlink untuk meningkatkan peringkat dan authority

\section{Link Spam (VI)}

Hindari / Jangan dilakukan:

- Backlink generator

- Link excange

- Hidden backlink

Tabel 4.8. Violations Factor

\begin{tabular}{|c|c|c|}
\hline $\begin{array}{c}\text { Factor } \\
\text { Code }\end{array}$ & $\begin{array}{c}\text { Category \& } \\
\text { Segment }\end{array}$ & \multicolumn{1}{|c|}{ Indicators } \\
\hline $\mathrm{Vt}$ & $\begin{array}{c}\text { "Content" } \\
\text { Thin }\end{array}$ & $\begin{array}{l}\text { Apakah halaman } \\
\text { memiliki konten yang } \\
\text { sedikit dan kurang } \\
\text { substansi? }\end{array}$ \\
\hline $\mathrm{Vc}$ & $\begin{array}{c}\text { "Architecture" } \\
\text { Cloacking }\end{array}$ & $\begin{array}{l}\text { Apakah website } \\
\text { menunjukan hasil } \\
\text { halaman yang } \\
\text { berbeda antara mesin } \\
\text { pencari dan manusia? }\end{array}$ \\
\hline
\end{tabular}

\begin{tabular}{|c|c|l|}
\hline VS & $\begin{array}{c}\text { "HTML" } \\
\text { Stuffing }\end{array}$ & $\begin{array}{l}\text { Apakah konten } \\
\text { menggunakan kata } \\
\text { kunci yang } \\
\text { berlebihan dengan } \\
\text { maksud halaman } \\
\text { dapat ditemukan } \\
\text { untuk itu? }\end{array}$ \\
\hline Vh & $\begin{array}{c}\text { "HTML" } \\
\text { Hidden }\end{array}$ & $\begin{array}{l}\text { Apakah warna atau } \\
\text { desain tampilan } \\
\text { website } \\
\text { menyembunyikan } \\
\text { "kata kunci/kalimat" } \\
\text { dengan maksud } \\
\text { halaman dapat } \\
\text { ditemukan untuk itu? }\end{array}$ \\
\hline Vd & "Trust" & $\begin{array}{l}\text { Apakah website telah } \\
\text { ditandai sebagai } \\
\text { pembajak konten dari } \\
\text { website lainnya? }\end{array}$ \\
\hline Va & "Trust" & $\begin{array}{l}\text { Apakah konten } \\
\text { website susah } \\
\text { ditemukan diantara } \\
\text { anyak iklan? }\end{array}$ \\
\hline Ads & "Link" & $\begin{array}{l}\text { Apakah pihak } \\
\text { Universitas membeli } \\
\text { link dengan harapan } \\
\text { menjadi lebih baik di } \\
\text { hasil pencarian? }\end{array}$ \\
\hline Paid & Spam & $\begin{array}{l}\text { Apakah pihak } \\
\text { Universitas } \\
\text { melakukan spamming } \\
\text { link di forum, blog } \\
\text { maupun tempat } \\
\text { lainnya? }\end{array}$ \\
\hline
\end{tabular}

\section{Kesimpulan dan Saran}

Reengineering website Universitas Ma Chung berbasis Search engine Optimization (SEO) merupakan perancangan ulang yang menerapkan usaha-usaha dalam mengoptimasi website terhadap mesin pencari untuk mendapatkan peringkat yang lebih baik di hasil pencarian / SERP (Search Engine Result Page). Official website Ma Chung adalah sarana utama pihak luar dalam mengetahui informasi resmi dari pihak Universitas sehingga memastikan konten website dibangun pada sinyal yang tepat terhadap mesin pencari adalah sebuah keharusan.

Laporan ini menghasilkan pedoman yang diharapkan dapat membantu pihak Universitas Ma Chung dalam mengoptimalkan kinerja website di pencarian lokal maupun global. Adapun urutan prioritas faktor pada On-ThePage SEO yang perlu diperhatikan oleh pihak Universitas Ma Chung saat ini menurut hasil analisa, diantaranya:

- Kategori “Content”: Quality, Fresh, Words, Research, Vertical, Answer 
- Kategori “Architecture": HTTPS,

Duplicate, Mobile, Crawl, URLs, Speed

- Kategori "HTML": Html Titles, Html Desc, Headers, Structure

Ringkasan hasil dari implementasi framework "The Periodic Table of SEO Success Factors" terhadap objek penelitian official website Universitas Ma Chung yang dapat dilihat pada lampiran laporan.

Adapun saran-saran yang dapat digunakan untuk mengembangkan laporan ini, terutama untuk penelitian yang membahas mengenai SEO yakni setiap faktor masih mempunyai anak pembahasan yang lebih detail yang dapat diulas lebih lanjut untuk melengkapi pengetahun setiap faktor penunjang kesuksesan optimasi mesin pencari (SEO) baik di On-Page maupun Off-Page SEO.

\section{Daftar Pustaka}

[1] Rony, Cahya, Deddy, 2014, Penerapan Teknik SEO (Search Engine Optimization SEO) pada Website Dalam Strategi Pemasaran Melalui Internet, Binus University, Jakarta.

[2] Search Engine Land, 24 Februari 2017, The Periodic Table of SEO Success Factors, http://searchengineland.com/seotable/

[3] Google Inc., 27 April 2017, How Search Works, https://www.google.com/search/howsearchwork s/ 